\title{
DEVELOPMENT TRENDS INNOVATIONS IN THE WORLD
}

\author{
Prodanova N.A. \\ Doctor of economic science, professor, Plekhanov Russian University of Economics, \\ Russian, Moscow, e-mail: prodanova@mail.ru
}

\begin{abstract}
The article analyzes the theoretical and practical issues of researching the financial market and the impact of innovation on the empowerment of financial and non-financial institutions. Innovative development of society has taken on particular importance in recent years in the era of virtualization, internetization and cloud technologies, when new financial instruments appeared. These technologies provide the ability to transfer money to other countries and continents, make instant payment for goods and services, save and generate information in the database, conduct operations with virtual currencies, receive and provide loans between individuals and legal entities. The study, some of the findings of which are presented in this article, is devoted to current trends in the development of the financial market in the context of diversification of innovations, including on the stock and currency exchanges.

Object of study - the global financial market. The subject of the research is innovative processes in financial markets.

The purpose of the study is to identify trends and prospects for the development of innovative processes in financial markets.

The research methodology is based on the logical alignment of the material and on the analysis of the state of the global financial market and drawing conclusions based on the results.

The scientific and practical significance of the work consists in the new presentation and systematization of innovative processes in financial markets.

Results of the research: further development of the financial market requires the development of information technology, the banking sector and the stock market.
\end{abstract}

Key words: economics, financial market, innovation, information technologies, peer-to-peer or equal lending.

Проданова Н.А.

Экономика ғылымдарының докторы, профессор, Плеханов атындағы Ресей экономикалық университеті,

Ресей, Мәскеу, e-mail: prodanova@mail.ru

\section{Әлемдегі инновациялық трендтердің дамуы}

Андатпа. Анықтау дамытудың үрдістерін және перспективаларын инновациялық процестердің қаржы нарықтарын зерттеу мақсаты болып табылады.

Мақалада теориялық және практикалық мәселелерін зерттеу бойынша қаржы нарығын және қаржылық және қаржылық емес институттардың ықпал ету мүмкіндіктерін кеңейту. Бұл технологиялар басқа елдер мен құрлықтарда ақша аудару жүргізуге, лезде тауарлар мен қызметтер үшін төлем, сақтауға және генерациялау ақпаратты деректер базасында операцияларды, виртуалды валюталармен алуға және беруге, кредиттерді жеке тұлғаларға және заңды тұлғалар арасында жүргізуге мүмкіндік береді. Бұл мақалада зерттеу жекелеген қорытындылары бойынша оған ұсынылған, қазіргі заманғы үрдістерге қаржы нарығын дамыту жағдайында әртараптандыру және инновацияларды, оның ішінде, қор және валюта биржаларына арналады.

Жұмыстың ғылыми және тәжірибелік маңыздылығы жаңа ұсыну және жүйелендіру инновациялық процестердің қаржы нарықтарын тұжырымдаудан тұрады.

Зерттеу әдістері: зерттеу және әдебиеттерді талдау, талдау, сараптамалық бағалау әдісі. 
Зерттеу нәтижелері: қаржы рыногын одан әрі дамыту, ақпараттық технологиялардың қажеттік саласын, банк секторы мен қор нарығын дамыту.

Түйін сөздер: экономика, қаржы нарығы, инновациялар, ақпараттық технологиялар, тең-теңімен немесе тең кредиттеу.

Проданова Н.А.

Доктор экономических наук, профессор Российской экономической академии им. Плеханова, Россия, г. Москва, e-mail: prodanova@mail.ru

\title{
Развитие инновационных трендов в мире
}

\begin{abstract}
Аннотация. Исследование, отдельные выводы которого представлены в данной статье, посвящено современным тенденциям развития финансового рынка в условиях диверсификации инноваций, в том числе на фондовой и валютной биржах.

В статье анализируются теоретические и практические вопросы по исследованию финансового рынка и влияния инноваций на расширение возможностей финансовых и нефинансовых институтов. Особенно значимое инновационное развитие общества произошло в последние годы, в эпоху виртуализации, интернетизации и облачных технологий, когда появились новые финансовые инструменты. Данные технологии предоставляют возможности перевода денег в другие страны и континенты, производить мгновенную оплату за товары и услуги, сохранять и генерировать информацию в базе данных, производить операции с виртуальными валютами, получать и предоставлять кредиты между физическими и юридическими лицами.

Объект исследования - глобальный финансовый рынок. Предметом исследования являются инновационные процессы на финансовых рынках.

Цель исследования заключается в выявлении тенденций и перспектив развития инновационных процессов на финансовых рынках.

Методология исследования основана на логическом выстраивании материала и на анализе состояния глобального финансового рынка и получении выводов на основе научно-практических результатов.

Научная и практическая значимость работы состоит в новом представлении и систематизации инновационных процессов на финансовых рынках.

Результаты исследования: дальнейшее развитие финансового рынка требует развития сферы информационных технологий, банковского сектора и фондового рынка.

Ключевые слова: экономика, финансовый рынок, инновация, информационные технологии, пиринговое или равноправное кредитование.
\end{abstract}

Introduction. The development of innovative processes in financial markets concerns the securitization of financial markets and financial assets, the design of new financial instruments and the emergence of structured financial products.

Innovation processes associated with the formation of a new global financial market architecture, and the peculiarities of this process in new countries with market economies, can serve as an example of global changes in the global economy (Nikolay Berzon, Tamara Teplova, 2013).

The basis of the economy of any country is a banking system with traditional services within strictly regulated limits on weekdays according to the schedule of the working day. The development of information technology has led to the emergence of a new generation of financial companies that allow the use of traditional banking products through applications on mobile phones, tablets, laptops or computers. New type of financial institutions include on- line microfinance institutions (MFIs), Internet banks, crowdsourcing platforms, and peer-to-peer lending systems (p2p or peer-to-peer) (Sharip B, 2016).

Literature review. Currently, much attention is paid to innovation, since the development of information technologies and the emergence of new technologies opens up new opportunities for economic development. The most actively developing financial sector, which, in turn, prevails in the banking sector, which, unlike other enterprises, has its own and borrowed funds. The challenge for banks and other financial institutions is to attract customers and their financial resources with which you can earn money. As a result, banks should create attractive conditions and individually focus on each client, as an expert on banking innovations, J.P. Nichols (J.P. Nichols, 2017).

Financial institutions that accumulate cash and other assets can invest accumulated funds in innovative projects, including in the following areas (J.P. Nichols, 2017):

- automation; 
- robotics;

- information security.

- change user interface;

- development of digital marketing and sales;

- improved analysis and so on.

- development of digital competencies;

- changing information technology architecture;

- creation of a new digital bank;

- use of innovative proposals and other customer-oriented improvements.

Every year, new operations, players, changing terminology, new financial technologies or Fintech appear on the global financial market. Currently, Fintech is a whole industry consisting of companies that use technology and innovation to compete with traditional financial institutions represented by banks and intermediaries in the financial services market. Currently, Fintech includes technology start-ups and organizations that seek to improve and optimize their financial services.

Professor Patrick Schueffel from the Friborg School of Management reviewed more than 200 scientific articles published over the past forty years that mention the term "Fintech" and brought out the definition that Fintech is a new financial sector that uses innovative technologies to improve financial performance (German Gref, 2017):

The Fintech term generally refers to new applications, processes, products, or business models in the financial services industry, consisting of one or more additional financial services, including automation, trade insurance, and risk management (Sharip B. Sh., 2016). These services are provided entirely or mainly via the Internet. Various independent service providers, including at least one licensed bank or insurance company, may provide services. The interaction is provided through APIs (application programming interface) and is often governed by specific laws and regulations, such as the European Payment Services Directive.

Materials and methods: study and analysis of literature, deduction, analysis, method of expert assessments, expert assessments, inductive and deductive analysis, classification and group, historical, economical, and statistical methods. Their combination allows providing necessary degree of depth and universality of a research, validity of its conclusions.

Analys of innovative processes in the financial market includes the following factors.

The greatest number of innovations occurs in the following traditional areas of financial services (Barnett H.G, 1953):

1. Payments and money transfers: verification of identity and creation of accounts in which you can keep money, funds for depositing and withdrawing money and systems for the safe exchange of money between different parties,

2 . Deposit and credit operations that accumulate money from investors and borrowers

3. Managing capital and investments in the stock market, as well as planning pension savings and real estate.

4. Insurance of property of legal entities and individuals and personal insurance.

5. Currency and account management.

Results and discussion. Payment systems that combine payment functions and methods of transferring or receiving money, including electronic fiat money based on networks, smart cards based on fiat electronic money, and electronic money based on private networks, are popular.

The most famous Fiat-based electronic money networks:

- PayPal - American payment system. As of 2017, PayPal operates in 202 countries (although not all of them provide a full range of services), has more than 200 million registered users, works with 25 national currencies. In the case of purchases, an important feature of PayPal is to provide security guarantees for both the buyer and the seller;

- QIWI - Russian payment system, which is used in Russia, Kazakhstan, Moldova, Belarus, Romania, USA, Ukraine and the United Arab Emirates;

- American payment system Payoneer, which has about four million users in more than 200 countries and territories, and provides cross-border transactions in more than 150 local currencies, using its banking network throughout the world to make local bank transfers;

- Payment system M-Pesa -African, which operates in Kenya and Tanzania. The name means "M" system, which is used in mobile devices, and "Pesah" in Swahili means money. This system is designed to transfer mobile, financial and microfinance mobile phones released in 2007 to Vodafone for Safaricom and Vodacom, the largest mobile operators in Kenya and Tanzania (Barnett H.G, 1953).

Fintech companies use the latest developments in the field of mobile payments, online lending, digital money transfer and other technologies in building their businesses. These organizations offer their services exclusively through the Internet and can work all over the world without the need to meet with their clients in person. The network business model allows 
you to significantly reduce costs, which makes it possible to offer customers financial products on the most favorable terms. Special programs for smartphones allow you to take into account the individual preferences of users and their needs are met as fully as possible in the shortest possible time. At the same time, financial products are becoming more accessible to all categories of the population, and small and medium businesses receive new sources of financing.

Digital credit organizations use advanced scoring systems to assess the creditworthiness of potential borrowers based on Big Data technology or massive amounts of data using statistical methods and mathematical calculations.

Government regulators do not pay close attention to fintech companies, unlike traditional banking systems, which gives fintech additional competitive advantages. To retain its position in the market, Fintech companies are expanding their network and developing new products and services, which leads to the emergence of innovations in world markets.

In connection with the intensification of competition, new financial and information, products emerge, financial advisers possessing powerful artificial intelligence (AI). Plastic cards will be gradually replaced by contactless mobile payments and the financial flow of documents will become completely digital.

Banks operating offline, to enhance their competitiveness, buy shares in fintech companies and create their own online divisions. The world's largest banks are reducing the network of their branches, since the online service does not require large premises and staff.

In the past decade, peer-to-peer lending systems have become popular, also called "p2p", peer-to-peer or person-to-person lending, which means "person-to-person" financing. In some sources, this type of financing is called "equal lending, equitable investment or social loan.

A P2P loan is a way of borrowing money from unrelated persons or "equal parties" without the participation of a financial intermediary in the person of a bank, MFI or other financial institution.

This service is provided on special Internet sites where both parties must register. The lender must be registered, replenish a bank account and form an offer to customers in electronic form. The borrower also fills out a form with personal data, including employment information, income, and leaves a request with acceptable conditions. Thus, peer-to-peer loans are provided online on the websites of special lending institutions through the use of lending platforms and credit check tools, mainly credit scoring.

Equal loans, as a rule, belong to the category of unsecured personal loans, as they are issued to an individual, without collateral. Peering loans can be provided to small enterprises by agreement of the parties. Interest rates are set by lenders (lenders) competing for a lower rate in a reverse auction, or are determined by an intermediary company based on an analysis of the borrower's credit history.

Intermediary companies providing an Internet site are commercial entities; whose income is formed from the payment of borrowers for the provision of loans and for servicing the loan, while the amount of payment may be fixed or set as a percentage of the loan amount.

The first company that provided equal loans was Zopa (Zone of Possible Agreement) from the UK, established in 2005, which currently has more than half a million customers (Patric Schueffel, 2017). Then companies like RateSetter appeared in 2010, which used a collateral fund to protect lenders from borrower defaults, Funding Circle portal, ThinCats, Market Invoice, Assetz Capital.

Despite the lack of government regulation, equal lending in the UK focuses on standards developed by an independent Equal Financing Association. The Equal Financing Association obliges its members to take measures to service the loans, even in cases where the intermediary company is declared bankrupt. Also, the British government announced that from April 2014 this industry will be regulated by the Financial Operations Authority.

In the United States, the modern direction of equal lending was formed in February 2006, when Prosper, Lending Club began to operate in San Francisco, California, and other peerto-peer lending platforms opened. In 2008, the Securities and Exchange Commission (SEC) decided that equal loan companies register their bids as securities, in accordance with the US Securities Act of 1933. Lending Club and Prosper companies received approval from the SEC commission for issuing medium-term bonds to investors backed up by loan repayments. Lending Club and Prosper began working with FOLIO Investing to create a secondary market for their medium-term bonds, thus ensuring their liquidity for investors.

In 2009, the American non-profit organization Zidisha became the first peer-to-peer lending platform that works with lenders and borrowers from 
different countries and continents. This company also organized a risk assessment of borrowers in the absence of digital financial history facts.

In 2008, a social insurance site was launched in Bangalore, India, which finances local NonGovernmental Organizations (NGOs), which act as lenders. In 2017, the Central Bank of India Reserve Bank of India (RBI) published a report that presented research on the international market of peering lending. According to RBI data, there are crowded internet platforms in India, 30 of which specialize in lending to startups (McBride, Sarah, 2017).

Given the rapid development of the P2P market in India, and taking into account the international experience of peer-to-peer lending, RBI, in its report, considers the main regulatory models: an unregulated market; regulation of $\mathrm{P} 2 \mathrm{P}$ as a financial market; regulation of $\mathrm{P} 2 \mathrm{P}$ as a banking sector; American regulatory model; complete ban on doing business. All arguments for and against were taken into account, as a result of which it was decided to get the opinion of the participants of equal lending themselves to reduce risks for both lenders and borrowers.

In Australia, the first lender issuing equal loans in accordance with current requirements was SocietyOne, which since August 2012 has issued loans in the amount of more than 1.2 million US dollars. This company also introduced innovative mobile service technology, which accelerated the process of issuing loan applications and loan financing.

The Central Bank of Russia constantly monitors the crowdling market based on a sample of individual sites. The Agency of Strategic Initiatives, the Internet Initiatives Development Fund, Boomstarter and other participants in the financial market also voluntarily joined the monitoring (Trends in regulation, 2017).

In July 2016, a new player appeared on the financial market of Kazakhstan - the P2P lending project from Ules.kz. The peculiarity of the presented project is that the creditor is not a bank or a credit institution, but a large number of individuals or institutional investors. According to experts, such lending will not compete with banks, but is quite dangerous for the entire financial sector (Michel Tsoi, 2016). Experts fear causes a fairly high $45 \%$ lending rate, at which a large number of defaults or defaults are possible, since P2P loans are issued without collateral and are not secured in any way.
Ules P2P lending service is a platform that unites lenders, on the one hand, and borrowers, on the other, and the project is generated from Russian and Ukrainian peers. Ules.kz promises to provide low interest rates for borrowers, the opportunity to invest and independently choose a loan portfolio. P2P developers in Kazakhstan report that the main checks of a potential borrower in the $\mathrm{P} 2 \mathrm{P}$ platform will remain the same as in banks: credit history, pension contributions and personal data. The difference lies in the fact that Ules.kz will use a program that will analyze the profile of a potential borrower in social networks. The Big data analysis technology will allow analyzing the borrower's profile data in social networks, based on which the program will predict the likelihood of debt repayment or non-repayment. Ules.kz operates based on the Civil Code of the Republic of Kazakhstan, but the National Bank of the Republic of Kazakhstan is not yet regulated.

Depending on in which of the sectors the money supply of the economy is concentrated, one can judge the effectiveness of the financial market. For example, in Europe and developed Eastern countries, the financial market is focused on the securities market, insurance and investment. In addition, government securities and foreign currency in these countries are traded on the open market, that is, on the stock exchange.

It is noted that Islamic securities will not have demand in the financial market of the CIS countries, as they imply participation in the company's share. At the same time, the buyer of the security shares both the profits and losses of the company, but domestic investors are not ready to share the losses of the issuing company.

The banking system is developing; confidence is growing, from both investors and the public. However, since the financial sector cannot exist in isolation from the rest of the economy, it is affected by a decline in GDP, problems in the partner countries. Some optimize the work, others - are experiencing financial problems, so they redistribute the costs for other purposes.

Conclusion. Thus, the further development of the financial market requires the development of information technology, the banking sector and the stock market. The development of the foreign exchange market and the market of urgent operations, which smoothly flow from the banking sector to other companies that operate on the basis of Internet technologies, is important. This trend is developing and encompassing an increasing share of the financial market, and therefore requires special attention, including from the state. 


\section{References}

Barnett H.G. (1953) Innovation: the Basis of Cultural Change. New York : McGraw Hil. -P.7.

Innovation in financial markets. (2013) / Ed. Nikolay Berzon, Tamara Teplova. - M .: Higher School of Economics. P. 560.

German Gref. (2017) Banks and (vs) presentation report Fintech // materials of international financial Congress. P. 17.

Kyrgyzstan financial market - development prospects (2017) // Materials of the meeting of the Private Investors Club of Kyrgyzstan // http://www.senti.kg/article/financoviy rinok_kirgizctana_percpektivi_razvitiya.

Michael Tsoi. A new type of lending - P2P can be dangerous for the market (2016) // https: // www. kursiv. kz / news / finansy / novyj-vid- kreditovania-p2p- mozet-byt-opasnym- dla-rynka.

McBride, Sarah (2017). "AvantCredit Raises \$225 Million From Tiger Global, Peter Thiel". United States: Business Insider. Business Insider Inc.

McGuire P \& Conroy J. (2013) Fostering financial innovation for the poor The policy and regulatory environment. In: A. W. a. J. D. V. Pischke (ed) Private Finance for Human Development, USA, The Foundation for Development Cooperation.

Nicols J.P.. (2017) Innovation Strategy Leadership // http://jpnicols.com/.

Patrick Schueffel. (2017) Taming the Beast: A Scientific Definition of Fintech (engl.) // Journal of Innovation Management. Vol. 4, iss. four. P. 32-54.

Fiat electronic money based on smartcards (2016). / Site: https: // en. wikipedia http://www.ebXML.org/wiki Fiatnye_jelektronnye_dengi_na_baze_smart card reader.

Trends in regulation of peer-to-peer lending (Russia and India) (2017) // https: // penenza.ru / blogs / articles / trendy_regulirovaniya_piringovogo_kreditovaniya.

10 trends in the financial sector of Kyrgyzstan over the past few years (2016) // https: // Kaktus. Media / doc / $340470 \_10 \_$tendenciy_v_finansovom_sektore_kyrgyzstana_za_poslednie_neskolko_let.html.

Sharip B. Sh. (2016) Upravlenie innovatsionnymi technologiyami v meditsinckoy slushbe [Management of innovative technologies in the medical service]: the dissertation for the academic degree of "Doctor of Business Administration" / B. Sh. Sharp. AlmatyMoscow, ALMAU-RANKh. -125 p.

What does P2P means / Site: (2016) / // http://kredit-2014.ru/chto-soboj-predstavlyaet-piringovoe-kreditovanie/.

Werdigier, Julia (2012). "RIT Capital to Take Stake in British Financial Start-Up" (DealBook). New York, N.Y., United States: New York Times. The New York Times Company. 